\title{
Poziom sytuacyjnej wrażliwości edukacyjnej uczniów z uszkodzonym słuchem w momencie startu edukacyjnego
}

\begin{abstract}
Magdalena Olempska-Wysocka, Poziom sytuacyjnej wrażliwości edukacyjnej uczniów z uszkodzonym stuchem w momencie startu edukacyjnego [The level of situational educational sensitivity of students with hearing impairment at the time of the educational start]. Interdyscyplinarne Konteksty Pedagogiki Specjalnej, nr 20, Poznań 2018. Pp. 291-305. Adam Mickiewicz University Press. ISSN 2300-391X. DOI: 10.14746/ ikps.2018.20.15

Situational educational sensitivity is one of the components of the educational sensitivity model, which is the child's vulnerability to the implementation of tasks related to the role of the student. There are situational sensitivity of instrumental processes and situational educational sensitivity of directional processes. The study involved 74 children with hearing impairment in a profound and significant degree, beginning their studies in the first grade in primary school. The research was carried out in the first semester, in central Poland, in integration and special schools. The aim of the research was to determine the situational level of sensitivity of deaf pupils starting school education. The conducted research allows to determine which of the ranges are the best and the least developed, which enables orientation towards the rehabilitation and therapeutic interactions of this group of students.
\end{abstract}

KEY WORDS: school maturity, child with hearing impairment, educational sensitivity, preparing the child to start school 


\section{Wprowadzenie}

Pojęcie wrażliwości edukacyjnej stanowi teoretyczny model wyjaśniający pewne zachowania i czynności dziecka. Jest konstruktem poznawczym, ale również prognostycznym, określającym potencjalne możliwości dziecka do podejmowania zadań szkolnych. Wrażliwość edukacyjna wyraża się zatem $\mathrm{w}$ efektywności poznawania, które jest wzmacniane chęcią uczestniczenia w tych działaniach. Opierając się na koncepcji hierarchicznej struktury zdolności, Joanna Głodkowska opracowała model wrażliwości edukacyjnej w którym wyodrębniła: zadaniową wrażliwość edukacyjną, sytuacyjną wrażliwość edukacyjną i ogólną wrażliwość edukacyjną. Jak podkreśla autorka modelu, powyższe zakresy wrażliwości edukacyjnej występują we wzajemnych związkach, co pozwala na określenie całościowego obrazu szkolnego funkcjonowania dziecka ${ }^{1}$. Przedmiot rozważań $\mathrm{w}$ niniejszym artykule stanowi sytuacyjna wrażliwość edukacyjna uczniów z uszkodzonym słuchem².

Sytuacyjna wrażliwość edukacyjna odnosi się do sytuacji dydaktyczno-wychowawczych, z jakimi się spotyka i w których uczestniczy uczeń. Wyodrębniona w niej została praca zbiorowa - będąca formą organizacyjną, zabawa ruchowa (częsta metoda pracy z uczniem $\mathrm{w}$ wieku wczesnoszkolnym), jak również dwie indywidualne formy organizacyjne: samodzielna praca umysłowa i samodzielna praca manualna. Poszczególne kategorie metod i form organizacyjnych pozwalają na określenie poziomu uczestniczenia ucznia,

${ }^{1}$ J. Głodkowska, Wrażliwość edukacyjna w ksztattowaniu doświadczeń matematycznych u dzieci upośledzonych umysłowo w stopniu lekkim, Wyższa Szkoła Pedagogiki Specjalnej, Warszawa 1998.

2 Niniejszy artykuł stanowi fragment badań dotyczących wrażliwości edukacyjnej uczniów z uszkodzonym słuchem. Badania zostały przeprowadzone w roku szkolnym 2006/2007 oraz 2007/2008 i stanowią część badań zrealizowanych w ramach pracy doktorskiej. W Polsce, od tego czasu, nie podjęto się przeprowadzenia badań poruszających aspekt wrażliwości edukacyjnej osób z niepełnosprawnością słuchową. 
w tym ucznia $\mathrm{z}$ uszkodzonym narządem słuchu $\mathrm{w}$ tych formach i metodach pracy (procesy instrumentalne) oraz określenie poziomu motywacji i chęci (procesy kierunkowe) do podejmowania działań w pracy zbiorowej, zabawie ruchowej, samodzielnej pracy umysłowej oraz samodzielnej pracy manualnej ${ }^{3}$. Zgodnie z koncepcją autorki, sytuacyjna wrażliwość edukacyjna została podzielona na dwa zakresy:

1) sytuacyjna wrażliwość procesów instrumentalnych - świadcząca o psychofizycznych możliwościach ucznia podczas uczestnictwa w sytuacjach dydaktyczno-wychowawczych takich jak: praca zbiorowa, zabawa ruchowa, samodzielna praca umysłowa i samodzielna praca manualna;

2) sytuacyjna wrażliwość procesów kierunkowych - określająca motywację ucznia do uczestniczenia w pracy zbiorowej, zabawie ruchowej, samodzielnej pracy umysłowej oraz samodzielnej pracy manualnej.

Jak podkreśla Anna Brzezińska i współautorzy4, zmiana środowiska z przedszkolnego na szkolne stawia przed dzieckiem nowe wymagania, związane nie tylko z przyswajaniem nowej wiedzy, ale także $\mathrm{z}$ koniecznością wchodzenia w różnorodne interakcje zarówno w klasie, jak i w szkole z rówieśnikami oraz osobami dorosłymi, a także z samym sobą jako osobą uczącą się. Dlatego bardzo ważnym jest dostarczenie dziecku wsparcia w trakcie realizacji nowych dla niego zadań, odpowiednio wcześniej je do nich przygotować. Szczególnie trudna wydaje się być sytuacja dziecka z uszkodzonym słuchem, które rozpoczyna naukę szkolną. Jak pokazują badania własne ${ }^{5}$, najniższe wyniki w kategoriach wrażliwości edukacyjnej obejmujące zakres rozwoju mowy, zapamiętywania i odtwarzania,

${ }^{3}$ J. Głodkowska, Poznanie ucznia szkoty specjalnej, WSiP, Warszawa 1999.

${ }^{4}$ A. Brzezińska, J. Matejczuk, A. Nowotnik, Wspomaganie rozwoju dzieci z wieku od 5 do 7 lat a ich gotowość do radzenia sobie z wyzwaniami szkoty, "Edukacja” 2012, 1(117), s. 7-22.

${ }^{5}$ M. Olempska-Wysocka, Zadaniowa wrażliwość edukacyjna uczniów z uszkodzonym stuchem, „Szkoła specjalna” 2017, nr 4. 
a stanowią one dwa z pięciu najważniejszych obszarów gotowości szkolnej, które zostały wyodrębnione przez Sharon Kagan, Evelin Moore i Sue Breadekamp 6 .

\section{Badania własne}

Badania przeprowadzono na grupie 74 uczniów niesłyszących7, z rozwojem intelektualnym na poziomie normy, którzy rozpoczęli naukę w klasie pierwszej w szkole podstawowej. Badaniami objęto dzieci z terenu Polski centralnej, ze szkół integracyjnych i specjalnych. Za cel badań postawiono określenie poziomu sytuacyjnej wrażliwości uczniów z uszkodzonym słuchem, rozpoczynających naukę szkolną. Sformułowano następujące pytania badawcze, które poddano weryfikacji, stosując odpowiednie narzędzie pomiaru:

1. Jaki jest poziom sytuacyjnej wrażliwości edukacyjnej uczniów z uszkodzonym słuchem $\mathrm{w}$ momencie ich startu szkolnego?

2. Czy, a jeśli tak, to jakie są różnice w poziomie sytuacyjnej wrażliwości edukacyjnej warunkowanej formą kształcenia ucznia z uszkodzeniem słuchu?

3. Czy, a jeśli tak, to jakie są różnice w poziomie sytuacyjnej wrażliwości edukacyjnej uczniów z uszkodzonym słuchem, uwarunkowanych płcią badanych?

W badaniach zastosowano Arkusz Poznania Ucznia Szkoły Specjalnej J. Głodkowskiej z 1999 r. Poprzez obserwację uczestniczącą zachowań dzieci w sytuacjach naturalnych nauczyciel monitoruje, uczestniczy w czynnościach dziecka, rejestrując ich efekty. Kwestionariusz przeznaczony jest do badania wrażliwości edukacyjnej dzieci z niepełnosprawnością intelektualną, ale zgodnie z założeniami autorki Arkusza może być również stosowany w integracyj-

${ }^{6}$ Reconsidering children's early learning and development: Toward shared beliefs and vocabulary, red. S. Kagan, E. Moore, S. Bredekamp, National Education Goals Panel, Washington 1995.

7 Z uszkodzeniem słuchu w stopniu znacznym i głębokim. 
nych i ogólnodostępnych formach kształcenia. Trafność i rzetelność Arkusza kształtują się na wysokim poziomie $(r=0,98 ; \mathrm{p}<0,001)$

$\mathrm{w}$ diagnozowaniu gotowości szkolnej ucznia z lekką niepełnosprawnością intelektualną. Warto również podkreślić rolę prognostyczną narzędzia co do dalszych osiągnięć szkolnych uczniów ${ }^{8}$.

\section{Sytuacyjna wrażliwość edukacyjna uczniów z uszkodzonym słuchem w świetle badań własnych}

Wyniki badań dotyczące sytuacyjnej wrażliwości edukacyjnej uczniów z uszkodzonym słuchem $\mathrm{w}$ momencie startu szkolnego zostały zebrane w poniższej tabeli 1.

Jak wynika $\mathrm{z}$ danych zawartych $\mathrm{w}$ tabeli 1 , średnia wartość w kategorii sytuacyjnej wrażliwości edukacyjnej - do pracy zbiorowej, uzyskana przez uczniów z uszkodzonym słuchem wynosi 205,23 punktów, co stanowi 53,30\% maksymalnego wyniku, czyli niewiele ponad połowę. Wartość odchylenia standardowego wynosi 81,68 punktów, a stworzony w ten sposób przedział średnich wyników wynosi $(123,55 ; 286,91)$. Dolna granica odpowiada 32,09\% rezultatu maksymalnego, a górna 74,52\% możliwego do uzyskania. Zatem przeciętne wyniki w kategorii sytuacyjnej wrażliwości edukacyjnej do pracy zbiorowej mieszczą się $\mathrm{w}$ przedziale procentowym $(32,09 \% ; 74,52 \%)$. Wartość współczynnika skośności dla wyników w kategorii sytuacyjna wrażliwość edukacyjna do pracy zbiorowej jest dodatnia $(0,082)$. Rozkład jest zatem minimalnie asymetryczny i nieznacznie rozciąga się w kierunku rezultatów niższych. Wskaźnik skupienia (kurtoza) jest ujemny, rozkład jest zatem platykurtyczny. Platykurtyczność rozkładu sugeruje brak w badanej grupie uczniów z uszkodzonym narządem słuchu takich, którzy osiągają wyższe wyniki w tej kategorii niż pozostali. Jest wśród nich natomiast taka grupa, która uzyskała wyniki na podobnym sobie poziomie i to nieco powyżej uzyskanego przez całą badaną grupę.

${ }^{8}$ J. Głodkowska, Poznanie ucznia szkoty... 


\begin{tabular}{|c|c|c|c|c|c|c|c|c|c|c|c|c|}
\hline 00 & 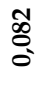 & 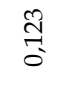 & $\begin{array}{l}\text { N } \\
\text { 12 } \\
0 \\
1\end{array}$ & $\begin{array}{l}F \\
\overline{0} \\
0 \\
i\end{array}$ & $\begin{array}{l}\stackrel{\Delta}{O} \\
\text { O }\end{array}$ & $\begin{array}{l}20 \\
\infty \\
\infty \\
\rightarrow\end{array}$ & $\begin{array}{l}\text { స̃ } \\
\text { ָ̦ } \\
\text { ì }\end{array}$ & $\begin{array}{l}\vec{n} \\
\stackrel{2}{0} \\
\end{array}$ & $\begin{array}{l}\text { J゙ } \\
\stackrel{0}{0} \\
\text { i }\end{array}$ & $\begin{array}{l}\text { \&్ } \\
\text { N̦ } \\
\text { i }\end{array}$ & $\begin{array}{l}\sqrt{n} \\
\stackrel{2}{0} \\
\text { i }\end{array}$ & $\begin{array}{l}\sigma \\
\hat{\sigma} \\
\hat{\sigma}\end{array}$ \\
\hline$\not{y}$ & 돈 & 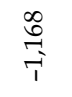 & 동 & $\begin{array}{l}\text { D' } \\
0 \\
0 \\
i \\
1\end{array}$ & $\begin{array}{l}0 \\
\infty \\
\infty \\
i \\
i\end{array}$ & $\begin{array}{l}\text { సี } \\
\text { ले }\end{array}$ & $\begin{array}{l}\text { ठ্ } \\
\text { \& } \\
\text { i }\end{array}$ & $\begin{array}{l}\hat{\alpha} \\
\text { 1م. } \\
\text { î }\end{array}$ & $\begin{array}{l}\overrightarrow{5 n} \\
\stackrel{+}{+} \\
\stackrel{1}{1}\end{array}$ & $\begin{array}{l}\text { va } \\
\text { హे } \\
\text { i }\end{array}$ & $\begin{array}{l}\vec{\sigma} \\
\text { ò } \\
\end{array}$ & $\begin{array}{l}\text { ֻે } \\
\text { ్} \\
\sigma\end{array}$ \\
\hline $\begin{array}{l}\widehat{\infty} \\
\underbrace{2}+1 \\
\dot{x}\end{array}$ & 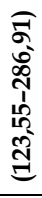 & 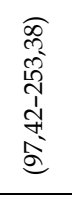 & 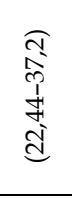 & 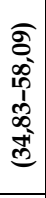 & 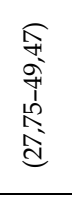 & $\begin{array}{l}\widehat{\sigma} \\
o \\
i \\
o \\
o \\
0 \\
0\end{array}$ & 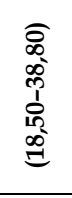 & 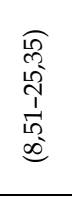 & 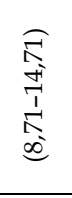 & 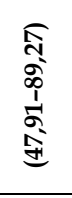 & 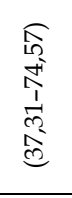 & 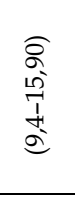 \\
\hline 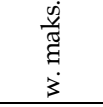 & 요 & $\frac{m}{\infty}$ & 가 & $\hat{\sigma}$ & $\begin{array}{l}\infty \\
10\end{array}$ & $a$ & in & $\stackrel{10}{m}$ & $\stackrel{\Perp}{\longrightarrow}$ & ๙ั & $\infty$ & $\stackrel{0}{=}$ \\
\hline $\begin{array}{l}\dot{\Xi} \\
\dot{\Xi} \\
\dot{3}\end{array}$ & $\boldsymbol{\beta}$ & F & $\infty$ & $\ddot{N}$ & $\stackrel{6}{\sim}$ & $r$ & 0 & 0 & + & สి & $\triangleq$ & H \\
\hline lis & ณ̊ & 몽 & 총 & $\stackrel{\infty}{\stackrel{0}{0}}$ & $\stackrel{10}{0}$ & $\begin{array}{l}\infty \\
\infty \\
0\end{array}$ & 菙 & $\stackrel{\infty}{+}$ & \begin{tabular}{l}
$\infty$ \\
\multirow{0}{0}{}
\end{tabular} & 동 & gి & $\frac{2}{0}$ \\
\hline 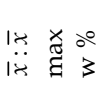 & $\begin{array}{l}\text { ले } \\
\text { గి }\end{array}$ & $\underset{⿱ 艹}{\stackrel{H}{H}}$ & $\underset{8}{8}$ & $\begin{array}{l}\text { నे } \\
\text { क् }\end{array}$ & $\begin{array}{l}\mathbb{4} \\
18\end{array}$ & $\underset{\infty}{\mathbb{N}}$ & î & $\begin{array}{l}\hat{\alpha} \\
\text { ơ } \\
\text { के }\end{array}$ & $\begin{array}{l}8 \\
\infty \\
\infty \\
\infty\end{array}$ & 疋 & જू & $\begin{array}{l}\text { ¿ } \\
\text { হ }\end{array}$ \\
\hline$\infty$ & $\underset{\infty}{\infty}$ & $\begin{array}{l}\stackrel{\infty}{2} \\
\hat{\Sigma}\end{array}$ & $\stackrel{\infty}{\stackrel{\infty}{N}}$ & $\begin{array}{l}\tilde{b} \\
\overrightarrow{=}\end{array}$ & $\begin{array}{l}\infty \\
\infty \\
\stackrel{0}{-1}\end{array}$ & $\stackrel{0}{\stackrel{0}{\digamma}}$ & $\stackrel{10}{\stackrel{2}{0}}$ & $\underset{\text { I }}{\stackrel{\infty}{\infty}}$ & $\begin{array}{l}8 \\
\text { ल) }\end{array}$ & $\begin{array}{l}\infty \\
\stackrel{\text { ¿ }}{0}\end{array}$ & $\begin{array}{l}\widetilde{\sigma} \\
\infty^{\circ}\end{array}$ & $\stackrel{\stackrel{1}{N}}{n}$ \\
\hline Ix & 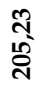 & $\begin{array}{l}\text { 여 } \\
\text { In } \\
\end{array}$ & $\begin{array}{l}\text { Dం } \\
\text { సે }\end{array}$ & $\begin{array}{l}\text { \&̊ } \\
\text { f́ }\end{array}$ & $\begin{array}{l}\overrightarrow{6} \\
\infty \\
\infty^{\circ}\end{array}$ & 这 & $\begin{array}{l}10 \\
\text { స్ }\end{array}$ & $\begin{array}{l}\Omega \\
\sigma \\
\sigma\end{array}$ & $\begin{array}{l}\vec{F} \\
\vec{F}\end{array}$ & $\begin{array}{l}\text { గ్ } \\
\text { क् }\end{array}$ & 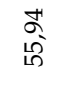 & \begin{tabular}{l}
18 \\
ஸे \\
\multirow{7}{*}{}
\end{tabular} \\
\hline$\sum_{3}^{i}$ & 冓 & कै & ㄱ & $\mathscr{0}$ & ถે & $a$ & เి & $\stackrel{1}{m}$ & $\stackrel{\Perp}{\longrightarrow}$ & ช้ & $\infty$ & $\stackrel{0}{\sim}$ \\
\hline Z & $\stackrel{N}{N}$ & $\mathbb{N}$ & $\mathbb{N}$ & $\mathbb{N}$ & $\mathbb{N}$ & $\stackrel{ \pm}{\Sigma}$ & $\mathbb{N}$ & $\stackrel{\star}{\Sigma}$ & $\mathbb{N}$ & $\mathbb{N}$ & $\mathbb{N}$ & $\stackrel{ \pm}{N}$ \\
\hline 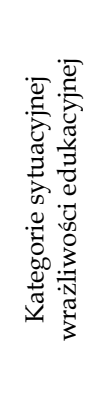 & 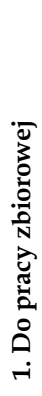 & 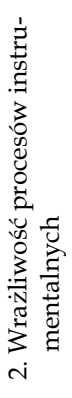 & 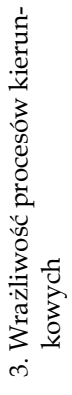 & 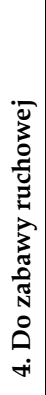 & 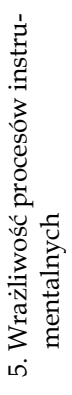 & 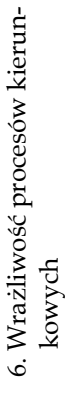 & 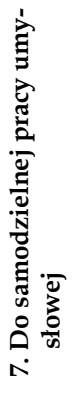 & 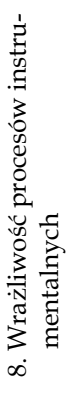 & 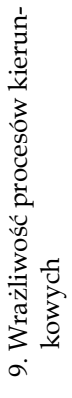 & 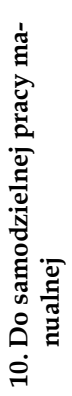 & 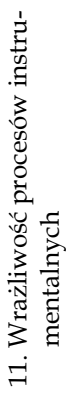 & 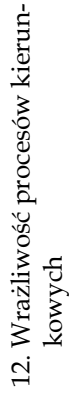 \\
\hline
\end{tabular}


Poziom sytuacyjnej wrażliwości edukacyjnej uczniów z uszkodzonym słuchem 297

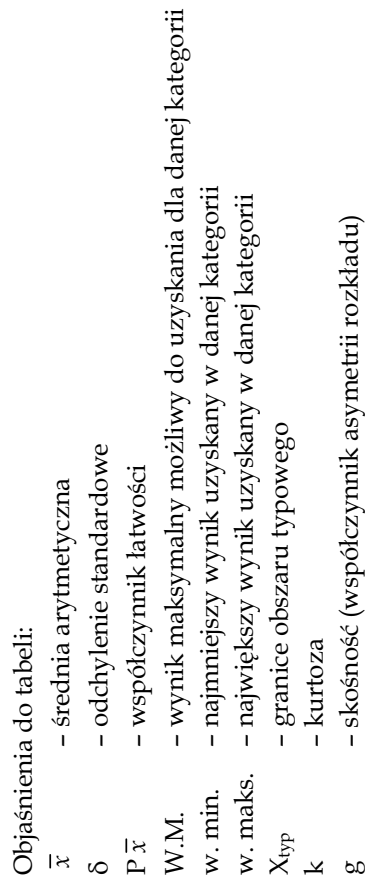


Wyniki uzyskane przez uczniów z uszkodzonym słuchem w momencie startu edukacyjnego w kategorii sytuacyjnej wrażliwości edukacyjnej - do zabawy ruchowej pozwalają zauważyć, że średnia wartość wynosi 46,46 punktów, co stanowi 68,32\% maksymalnego wyniku, możliwego do uzyskania, czyli niewiele ponad połowę, ale jest wyższy w porównaniu z sytuacyjną wrażliwością badanych uczniów do pracy zbiorowej. Wartość odchylenia standardowego wynosi 11,63 punktów, a przedział przeciętnych wyników to $(34,53$; $58,09)$. Dolna granica odpowiada 51,22\% rezultatu maksymalnego, a górna 85,42\% możliwego do uzyskania w tej kategorii sytuacyjnej wrażliwości edukacyjnej. Warto też zauważyć fakt, że ponad połowa badanych uczniów z uszkodzonym słuchem (51,22\%) osiągnęła niskie wyniki w tej kategorii. Analiza współczynnika asymetrii pozwala wnioskować, że mamy tutaj do czynienia z rozkładem minimalnie lewostronnym. Natomiast współczynnik skupienia jest ujemny i informuje nas, podobnie jak w sytuacyjnej wrażliwości edukacyjnej do pracy zbiorowej o platykurtyczności rozkładu. Analiza materiału badawczego ujawniła również wysoką wrażliwość procesów kierunkowych dzieci z uszkodzonym słuchem do uczestniczenia w zabawie ruchowej $(87,22 \%)$, przy stosunkowo niższym poziomie procesów instrumentalnych $(65,44 \%)$. Dane te potwierdzają wielokrotnie podkreślaną przez pedagogów i psychologów naturalną dla dziecka wartość zabawy, w tym także zabawy ruchowej.

Przyglądając się rezultatom w kategorii sytuacyjnej wrażliwości edukacyjnej - do samodzielnej pracy umysłowej, można zauważyć, że średnia wartość wynosi 28,65 punktów, co stanowi 57,30\% maksymalnego wyniku. Z kolei wartość odchylenia standardowego wynosi 10,15 punktów, a stworzony w ten sposób przedział średnich wyników wynosi $(18,5 ; 38,80)$. Dolna granica odpowiada 37\% rezultatu maksymalnego, a górna 77,6\% możliwego do uzyskania. Zatem przeciętne wyniki w kategorii sytuacyjnej wrażliwości edukacyjnej do samodzielnej pracy umysłowej mieszczą się w przedziale procentowym $(37 \% ; 77,6 \%)$. Współczynnik skupienia wokół średniej jest ujemny i informuje o platykurtycznym rozkładzie, świadczącym o zróżnicowaniu wyników uzyskanych przez badanych 
uczniów. Również wartość współczynnika asymetrii rozkładu wyników ma wartość ujemną, co przemawia za asymetrią lewostronną. Istotnym jest fakt, że jedną z najmniej korzystnych z punktu widzenia możliwości psychicznych ucznia, jest jego uczestniczenie w samodzielnej pracy umysłowej (57,3\% wyniku maksymalnego), a w tym zakresie niska wartość procesów instrumentalnych $(48,37 \%$ wyniku maksymalnego) i stosunkowo wyższa wrażliwość procesów kierunkowych (78,06\% wyniku maksymalnego). Wyniki te stanowią potwierdzenie odnotowanej w zakresie analizy ogólnej wrażliwości edukacyjnej, niski poziom dojrzałości uczniów z uszkodzonym słuchem, rozpoczynających naukę szkolną do sprostania zadaniom wymagającym operacyjnego rozumowania. Warto pamiętać o tym, że wiedza o niskim poziomie wrażliwości edukacyjnej uczniów do sprostania zadaniom, które wymagają operacyjnego rozumowania powinna mieć swoje odzwierciedlenie w konstruowanych sytuacjach dydaktycznych i zadaniach na miarę możliwości uczniów z uszkodzonym słuchem.

Na uwagę zasługują stosunkowo wyższe wyniki w kategorii sytuacyjnej wrażliwości edukacyjnej - do samodzielnej pracy manualnej. Średnia uzyskana przez uczniów z uszkodzonym słuchem wynosi 68,59 punktów, co stanowi 71,44 \% maksymalnego wyniku. Wartość odchylenia standardowego to 20,68 punktów, a stworzony w ten sposób przedział średnich wyników wynosi $(47,91 ; 89,27)$. Dolna granica odpowiada 49,9\% rezultatu maksymalnego, a górna 92,9\%. Zatem przeciętne wyniki w kategorii sytuacyjnej wrażliwości edukacyjnej do samodzielnej pracy umysłowej mieszczą się w przedziale procentowym (37\%; 77,6\%). Różnica pomiędzy uczniami o przeciętnie najsłabszej sytuacyjnej wrażliwości edukacyjnej do samodzielnej pracy umysłowej a uczniami z najwyższą sytuacyjną wrażliwością edukacyjną do samodzielnej pracy umysłowej wynosi 43,6\%. Współczynnik asymetrii rozkładu wyników, jak i współczynnik skupienia wokół średniej, osiągają wartości ujemne, co pozwala na stwierdzenie, że mamy tutaj do czynienia z rozkładem platykurtycznym oraz asymetrią lewostronną, gdzie większe liczebności skupiają się w zakresie większej wartości zmiennej. Warto 
zauważyć, że podobnie jak w poprzednich kategoriach sytuacyjnej wrażliwości edukacyjnej, również i w przypadku samodzielnej pracy manualnej wyróżnia się przewaga procesów kierunkowych nad instrumentalnymi. W tym zakresie należy podkreślić chęci dzieci oraz ich zaangażowanie w sytuacje dydaktyczne $(79,06 \%)$, które angażują uczniów manualnie oraz zdają się sprawiać przyjemność, zadowolenie z wykonywanych czynności i spełnianych zadań.

Ponad to analiza wyników uzyskanych w trakcie przeprowadzonego procesu badawczego pozwala stwierdzić, że na stosunkowo wysokim poziomie (powyżej 0,70 współczynnika łatwości) kształtują się:

- wrażliwość procesów kierunkowych do zabawy ruchowej (87\% wyniku maksymalnego),

- wrażliwość procesów kierunkowych do samodzielnej pracy indywidualnej (79\% wyniku maksymalnego),

- wrażliwość procesów kierunkowych do samodzielnej pracy umysłowej (78\% wyniku maksymalnego),

- wrażliwość procesów kierunkowych do pracy zbiorowej (71\% wyniku maksymalnego).

Wykres 1. Zestawienie procentowe wyników oceny sytuacyjnej wrażliwości edukacyjnej uczniów z uszkodzonym słuchem

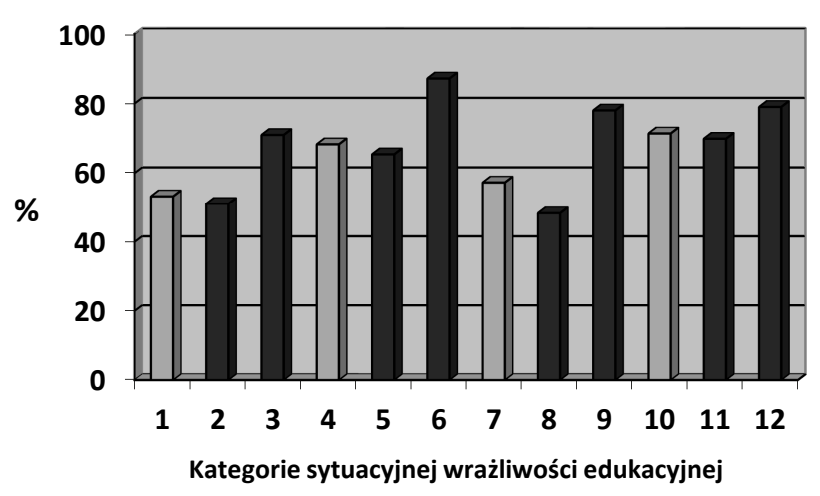


Można zatem stwierdzić, że badana grupa uczniów z uszkodzonym narządem słuchu, rozpoczynających naukę w klasie pierwszej szkoły podstawowej wykazuje dość wysoki poziom motywacji, chęci oraz zaangażowania w sytuacje dydaktyczne obejmujące: pracę zbiorową, zabawy ruchowe, samodzielną pracę umysłową oraz samodzielną pracę indywidualną. Stosunkowo niższe wyniki $\mathrm{w}$ poszczególnych kategoriach sytuacyjnej wrażliwości edukacyjnej, a dotyczące procesów instrumentalnych mogą wskazywać na konieczność korzystniejszego dostosowania form i metod pracy z uczniem $\mathrm{z}$ uszkodzonym słuchem, rozpoczynającego naukę $\mathrm{w}$ klasie pierwszej. J. Głodkowska ${ }^{9}$ zwraca uwagę na fakt, że dziecko w momencie startu edukacyjnego przejawia większą potrzebę działania, niż wskazują na to jego możliwości sprostania zadaniom. Dotyczy to zwłaszcza: pracy zbiorowej, zabawy ruchowej, samodzielnej pracy umysłowej czy też samodzielnej pracy manualnej. Wniosek ten doprowadza do następującego wskazania pedagogicznego - nauczyciel powinien za pomocą umiejętnych, pedagogicznych i psychologicznych zabiegów, wykorzystać chęć dziecka, sprawić by zaangażowanie dynamizowało siły psychiczne, by chęć nie wygasła, lecz mobilizowała do wysiłku.

Graficzna prezentacja uzyskanych wyników badań, na podstawie procentowych wyników maksymalnych, została przedstawiona na wykresie 1.

\section{Analiza porównawcza poziomu sytuacyjnej wrażliwości edukacyjnej dziewcząt i chłopców z uszkodzonym narządem słuchu}

W przeprowadzonych badaniach analizie poddano również różnice w sytuacyjnej wrażliwości edukacyjnej badanych uczniów z uszkodzonym słuchem $\mathrm{w}$ momencie startu edukacyjnego $\mathrm{z}$ uwzględnieniem zmiennej płeć. Zestawienie wyników uzyskanych przez obie grupy (dziewcząt i chłopców) przedstawia tabela 2.

\footnotetext{
${ }^{9}$ Głodkowska J., Wrażliwość edukacyjna w kształtowaniu...
} 
Tabela 2. Zestawienie wyników uzyskanych przez dziewczęta i chłopców z uszkodzonym narządem słuchu w zakresie sytuacyjnej wrażliwości edukacyjnej

\begin{tabular}{|c|c|c|c|c|c|c|c|}
\hline \multirow[b]{2}{*}{$\begin{array}{c}\text { Kategorie sytuacyjnej } \\
\text { wrażliwości edukacyjnej }\end{array}$} & \multirow[b]{2}{*}{ Płeć } & \multirow[b]{2}{*}{$\mathrm{N}$} & \multirow[b]{2}{*}{$\begin{array}{l}\text { Średnia } \\
\text { rang }\end{array}$} & \multirow[b]{2}{*}{$\begin{array}{l}\text { Suma } \\
\text { rang }\end{array}$} & \multicolumn{3}{|c|}{ Statystyki testu } \\
\hline & & & & & $\begin{array}{l}\text { U Manna- } \\
\text {-Whitneya }\end{array}$ & $\mathrm{Z}$ & $\begin{array}{l}\text { Istotność asymp- } \\
\text { totyczna (dwu- } \\
\text { stronna) }\end{array}$ \\
\hline \multirow{2}{*}{ 1. Do pracy zbiorowej } & $\mathrm{K}$ & 31 & 37,34 & 1157,50 & \multirow{2}{*}{661,500} & \multirow{2}{*}{$-0,055$} & \multirow{2}{*}{0,956} \\
\hline & $\mathrm{M}$ & 43 & 37,62 & 1617,50 & & & \\
\hline \multirow{2}{*}{ 2. Do zabawy ruchowej } & $\mathrm{K}$ & 31 & 39,42 & 1222,00 & \multirow{2}{*}{607,000} & \multirow{2}{*}{$-0,652$} & \multirow{2}{*}{0,514} \\
\hline & $\mathrm{M}$ & 43 & 36,12 & 1553,00 & & & \\
\hline \multirow{2}{*}{$\begin{array}{l}\text { 3. Do samodzielnej pracy } \\
\text { umysłowej }\end{array}$} & $\mathrm{K}$ & 31 & 38,21 & 1184,50 & \multirow{2}{*}{644,500} & \multirow{2}{*}{$-0,241$} & \multirow{2}{*}{0,809} \\
\hline & M & 43 & 36,99 & 1590,50 & & & \\
\hline \multirow{2}{*}{$\begin{array}{l}\text { 4. Do samodzielnej pracy } \\
\text { manualnej }\end{array}$} & K & 31 & 37,76 & 1170,50 & \multirow{2}{*}{658,500} & \multirow{2}{*}{$-0,088$} & \multirow{2}{*}{0,930} \\
\hline & M & 43 & 37,31 & 1604,50 & & & \\
\hline
\end{tabular}

Objaśnienia jak do tabeli 1.

Porównując poziom sytuacyjnej wrażliwości edukacyjnej dziewcząt i chłopców z uszkodzonym słuchem w odniesieniu do sytuacji dydaktyczno-wychowawczych, nie stwierdza się istotnych różnic pomiędzy badanymi grupami. Rezultaty badań wskazują jednocześnie, że dziewczęta z uszkodzonym narządem słuchu, prezentują wyższy poziom w zakresie sytuacyjnej wrażliwości edukacyjnej do:

- zabawy ruchowej,

- samodzielnej pracy umysłowej,

- samodzielnej pracy manualnej.

Chłopcy z kolei uzyskali wynik świadczący o wyższym poziomie wrażliwości do pracy zbiorowej. Jak już zostało wspomniane, rozbieżności w uzyskanych wynikach nie są istotne statystycznie. Nie można zatem stwierdzić, że płeć jest czynnikiem różnicującym w zakresie czterech kategorii sytuacyjnej wrażliwości edukacyjnej.

W przeprowadzonych badaniach dokonano również analizy statystycznej pomiędzy poziomem sytuacyjnej wrażliwości edukacyjnej a rodzajem szkoły do jakiej uczęszcza dziecko. Zestawienie wyników zawiera tabela 3. 
Tabela 3. Poziom sytuacyjnej wrażliwości edukacyjnej uczniów z uszkodzonym słuchem w momencie startu edukacyjnego, z uwzględnieniem rodzaju szkoły do jakiej uczęszcza dziecko

\begin{tabular}{|c|c|c|c|c|c|c|c|}
\hline $\begin{array}{l}\text { Kategorie sytua- } \\
\text { cyjnej wrażliwości } \\
\text { edukacyjnej }\end{array}$ & $\begin{array}{l}\text { Rodzaj } \\
\text { szkoły }\end{array}$ & $\mathrm{N}$ & $\begin{array}{l}\text { Średnia } \\
\text { ranga }\end{array}$ & $\begin{array}{c}\text { Suma } \\
\text { rang }\end{array}$ & $\begin{array}{l}\text { U Manna- } \\
\text {-Whitneya }\end{array}$ & Z & $\begin{array}{c}\text { Istotność asymp- } \\
\text { totyczna (dwu- } \\
\text { stronna) }\end{array}$ \\
\hline \multirow{2}{*}{$\begin{array}{l}\text { 1. Do pracy zbio- } \\
\text { rowej }\end{array}$} & integracyjna & 28 & 54,11 & 1515,00 & \multirow{2}{*}{179,000} & \multirow{2}{*}{$-5,183$} & \multirow{2}{*}{0,000} \\
\hline & specjalna & 46 & 27,39 & 1260,00 & & & \\
\hline \multirow{2}{*}{$\begin{array}{l}\text { 2. Do zabawy } \\
\text { ruchowej }\end{array}$} & integracyjna & 28 & 52,16 & 1460,50 & \multirow{2}{*}{233,500} & \multirow{2}{*}{$-4,578$} & \multirow{2}{*}{0,000} \\
\hline & specjalna & 46 & 28,58 & 1314,50 & & & \\
\hline \multirow{2}{*}{$\begin{array}{l}\text { 3. Do samodzielnej } \\
\text { pracy umysłowej }\end{array}$} & integracyjna & 28 & 51,88 & 1452,50 & \multirow{2}{*}{241,500} & \multirow{2}{*}{$-4,491$} & \multirow{2}{*}{0,000} \\
\hline & specjalna & 46 & 28,75 & 1322,50 & & & \\
\hline \multirow{2}{*}{$\begin{array}{l}\text { 4. Do samodzielnej } \\
\text { pracy manualnej }\end{array}$} & integracyjna & 28 & 50,75 & 1421,00 & \multirow{2}{*}{273,000} & \multirow{2}{*}{$-4,138$} & \multirow{2}{*}{0,000} \\
\hline & specjalna & 46 & 29,43 & 1354,00 & & & \\
\hline
\end{tabular}

Objaśnienia jak do tabeli 1.

Zebrany materiał empiryczny pozwala na stwierdzenie, że istnieje statystycznie istotna różnica pomiędzy czterema kategoriami sytuacyjnej wrażliwości edukacyjnej (do pracy zbiorowej, zabawy ruchowej, samodzielnej pracy umysłowej, samodzielnej pracy manualnej) a rodzajem szkoły (integracyjna, specjalna) do jakiej uczęszcza dziecko. Istotności asymptotyczne dla każdej kategorii są takie same i wynoszą $a=0,000$. Analiza średnich pozwala zauważyć, że wyższy poziom we wszystkich czterech kategoriach sytuacyjnej wrażliwości edukacyjnej osiągają uczniowie ze szkół integracyjnych.

\section{Podsumowanie}

Analiza materiału badawczego dotyczącego określenia poziomu sytuacyjnej wrażliwości edukacyjnej uczniów z uszkodzonym narządem słuchu pozwoliła na sformułowanie następujących wniosków: 
- w zakresie sytuacyjnej wrażliwości edukacyjnej uczniowie z uszkodzonym narządem słuchu prezentują najniższy poziom wrażliwości w pracy zbiorowej (53,30\%). Warto zauważyć, że wyniki dotyczące wszystkich czterech sytuacji dydaktyczno-wychowawczych (pracy zbiorowej, zabawy ruchowej, samodzielnej pracy umysłowej, samodzielnej pracy manualnej), kształtują się powyżej 50\% wyniku maksymalnego;

- płeć uczniów z uszkodzonym narządem słuchu nie jest czynnikiem istotnie różnicującym poziom sytuacyjnej wrażliwości edukacyjnej w pracy zbiorowej, zabawie ruchowej, samodzielniej pracy umysłowej czy też samodzielnej pracy manualnej;

- przeprowadzone badania wskazują, że istnieje istotna statystycznie różnica pomiędzy poziomem sytuacyjnej wrażliwości edukacyjnej a rodzajem szkoły do jakiej uczęszcza dziecko z uszkodzonym słuchem. Warto nadmienić, że wyższy poziom sytuacyjnej wrażliwości edukacyjnej osiągają uczniowie uczęszczający do szkół integracyjnych. Przedstawione wyniki badań pokazują także, że pomimo tego, że uczniowie ze szkół specjalnych uzyskują niższe wyniki, to charakteryzują się wyższym poziomem motywacji i osiągnięć szkolnych (choć wynik nie jest istotny statystyczny). Przyczyną takiego wyniku może być fakt, że uczniowie ze szkół specjalnych przeżywają mniejszy stres, są bardziej chronieni, czują się pewniej w środowisku rówieśniczym, nie są narażeni na kpiny. Ich stan emocjonalny jest stabilniejszy, nadający się do modelowania w pożądanym kierunku.

\section{Bibliografia}

Brzezińska A., Matejczuk J., Nowotnik A., Wspomaganie rozwoju dzieci z wieku od 5 do 7 lat a ich gotowość do radzenia sobie z wyzwaniami szkoty, „Edukacja” 2012, 1(117). Głodkowska J., Wrażliwość edukacyjna w kształtowaniu doświadczeń matematycznych u dzieci upośledzonych umysłowo w stopniu lekkim, Wydawnictwo WSPS, Warszawa 1998. 
Poziom sytuacyjnej wrażliwości edukacyjnej uczniów z uszkodzonym słuchem 305

Głodkowska J., Analiza czynnikowa wrażliwości edukacyjnej jako źródło poznania dzieci rozpoczynających nauke w klasie pierwszej szkoły specjalnej, „Psychologia Wychowawcza" 1999, nr 3.

Głodkowska J., Poznanie ucznia szkoty specjalnej. Wrażliwość edukacyjna dzieci upośledzonych umystowo w stopniu lekkim: diagnoza i interpretacja, WSiP, Warszawa 1999.

Olempska-Wysocka M., Zadaniowa wrażliwość edukacyjna uczniów z uszkodzonym stuchem, „Szkoła Specjalna” 2017, nr 4.

Reconsidering children's early learning and development: Toward shared beliefs and vocabulary, red. S. Kagan, E. Moore, S. Bredekamp, National Education Goals Panel, Washington 1995. 